\title{
THE FUNCTION OF (MATERNAL) CANNIBALISM IN THE BOOK OF LAMENTATIONS (2:20 \& 4:10)
}

\author{
Hendrik Bosman \\ Old and New Testament \\ Stellenbosch University
}

\begin{abstract}
Cannibalism is a sensitive subject that many commentaries on the Book of Lamentations pay little attention to. This article develops the possibility that the Book of Lamentations confronts YHWH with the affliction that He has caused the destruction of Jerusalem and that maternal cannibalism is the horrendous extreme of this divinely inflicted suffering. This suggestion is discussed against the background of a central motif in later Greco-Roman literature that the tyrant is the inverted Other. Cannibalism may then be interpreted as a motif in the polemics against tyranny by the author of Lamentations to depict YHWH as author of the misery experienced with the destruction of Jerusalem and thereafter.
\end{abstract}

Key Words: Lamentations 2:20, Lamentations 4:10, Anthropophagy, Cannibalism, Suffering

\section{Introduction}

What function does the double reference to (maternal) cannibalism have in the Book of Lamentations and does this topic warrant closer academic scrutiny? Cannibalism is a sensitive subject and many commentaries on the Book of Lamentations pay little attention to it. ${ }^{2}$

\footnotetext{
The following three quotations are mentioned to function as a brief reception history of the concept of cannibalism - the first quotation from Shakespeare indicates how cannibalism was initially perceived to be something exotic and that it was used as a synonym for the older concept of anthropophagy:

"The Cannibals that each other eat, The Anthropophagi and men whose heads, Do grow beneath their shoulders" (William Shakespeare, Othello, I iii, 143).

The nineteenth century quotation from Moby Dick seems to be an ironic reference to the prejudice against non-Christians and possibly people of colour:

"Better sleep with a sober cannibal than a drunken Christian" (Queequeg in Herman Melville, Moby Dick).

The quotation from Dostoyevsky presupposes that nothing can be more immoral than cannibalism:

"If you were to destroy in mankind the belief in immortality, not only love but every living force maintaining the life of the world would at once be dried up. Moreover, nothing then would be immoral, everything would be permissible, even cannibalism" (Fedor Dostoyevsky, Brothers Karamazov, Pt 1, Bk I, ch 6).

2 Carr (2010:171) provides a short summary of current scholarly consensus: "Lamentations were composed to commemorate the destruction of Jerusalem in 586, particularly on the holiday remembering the event, the Ninth of Av. Over time, however, these poems in Lamentations have come to serve as a cry over Jewish suffering of many kinds..."

Collins (2004:350) makes the cautious observation: "Only occasionally does Lamentations hint that the punishment is 'beyond measure' or indeed unjustifiable in its severity. For a more thorough reflection on the justice of God, we will have to wait for the book of Job."
} 
Is cannibalism as the eating of other human beings simply deviant social behaviour that violates expected rules and norms that cannot be condoned under any circumstances? ? $^{3}$ When in the early 1970s an aeroplane crashed in the Andes with forty members of a rugby team from Uruguay they eventually resorted to cannibalism when they realized that the search for them was called off and that they had no other food source. Can the cannibalism of the last example be described as a 'normal response to extreme circumstances' such as severe drought and famine? (Andersen \& Taylor 2002:205-206).

Old Testament scholarship has made several diverging suggestions to explain cannibalism in the Old Testament in general and maternal cannibalism in Lamentations 2:20 and 4:10 in particular:

- to illustrate the dehumanizing effect of famine or war (Gray 1964:523; Nelson 1987:189),

- as a social satire (LaBarbera 1984:637-651),

- as part of a "world-upside-down or mundus inversus" topos (Lasine 1991:27-53),

- as a curse for covenantal disobedience or breaking a treaty (Reinhartz 1994:43-65).

I would like to develop the recent suggestion by Salters (2010:28) that Lamentations confront YHWH with the affliction that He has caused the destruction of Jerusalem and that maternal cannibalism is the horrendous extreme of this divinely inflicted suffering. This suggestion will be developed against the background of a central motif in later GrecoRoman literature that the tyrant is the inverted Other (Harrill 2008:133-158). Cannibalism may then be interpreted as a motif in the polemics against tyranny by the author of Lamentations to depict YHWH as author of the misery experienced with the destruction of Jerusalem and thereafter.

\section{Cannibalism in the Ancient Near East and the Old Testament}

Throughout history, siege warfare and famine have caused cannibalism or as it was initially referred to 'anthropophagy'. In the Ancient Near East, examples will be cited from Sumerian, Babylonian and Assyrian literature - especially from curses related to treaties.

\section{Sumerian Curse of Agade (ca 2000 BCE)}

One of the earliest references to anthropophagy/cannibalism clearly relates it to a curse on a city (ANET 650):

"Direct their face to the city,

Curse Agade with a baleful curse:

'City, you who dared assault the Ekur - it is Enlil (whom you assaulted),

May the oxen-slaughterer, slaughter (his) wife (instead),

May your sheep-butcher, butcher his child (instead) ...'”

When Jeffrey Dahmer in 1991 pleaded guilty to eating fifteen men it caused a public outcry and everyone seemed to agree that this was unpardonable deviant behaviour.

4 The term 'cannibalism' is relatively new and is derived from the Spanish name for the Carib people of the West Indian islands who were notorious for their predilection for human flesh ('Carib' was probably mispronounced as 'Canib'?). Allegations about cannibalism in colonial times may have been triggered by Isabella, Queen of Spain, who made a decree according to which only cannibals could be legally enslaved. Thus the term 'cannibalism' was often used during colonialism to demonize those groups who were subjugated by the colonizers (Arens 1981). Despite its anachronistic ring 'cannibalism' will be used instead of 'anthropophagy' to describe incidents of the eating of human flesh prior to the emergence of the term 'cannibalism' in the late $15^{\text {th }}$ and early $16^{\text {th }}$ century. 
This four thousand year old document concerns a national catastrophe that was perceived to be the result of divine retribution that was triggered by human defiance. The author seems to be seeking for some explanation for the suffering caused by the catastrophe. Therefore, the desecration of the holiest shrine in Sumer, the Ekur, is identified as a suitable rationale for the calamity (Cooper 1983). The curse of Agade (the Sumerian name for the capital of the Akkadian Empire) was due to the attack on the city of Nippur by king Naram-Sin of Agade (Akkad) and the subsequent destruction of the holy shrine of Ekur.

Old Babylonian Atrahasis Epic (ca 1800 BCE):

A similar reference to cannibalism is found the creation epic Atrahasis D (i) $36-38$ and in D (ii) 48-51:

"When the sixth year arrived,

They prepared [the daughter] for food.

The child they prepared for food.

Filled were [...].

One house de[voured] the other."

Here cannibalism occurred due to prolonged famine (only in the sixth year) and extreme hunger caused by the gods. Thus cannibalism is not merely the result of human strife but of divine punishment.

Assyrian Treaties (Esarhaddon, Ashurbanipal - ca 800-600 BCE):

Although the different treaties are formulated with different nuances, many of them have in common that the breaking of the treaty will lead to cannibalism. Therefore cannibalism form part of the curses that motivated the parties to the treaty to adhere to the stipulations of the treaty.

In the Vassal Treaties of Essarhaddon, the following warnings can be found (ANET 537-539; 533b and 300a):

"Keep this treaty ... lest ... you deliver your land to destruction ..."

“... Mother shall (bar the door to) her daughter, may you eat in your hunger the flesh of your children, may one man eat the other's flesh through want and famine."

Ashurbanipal's campaign report against the Arabs (Rassam Cylinder) describes how Adia, queen of Arabia and Uate, the king of Arabia, were inflicted a bloody defeat and how many prisoners were taken to Babylon and Assyria (ANET 298-300):

"The remainder who succeeded to enter Babylon ate (there) each other's flesh in their ravenous hunger, and (later) they made a sortie from Babylon to save their lives" (v 2630). "Irra, the Warrior (i.e. pestilence) struck down Uate, as well as his army, who had not kept the oaths sworn to me and had fled before the onslaught of Ashur, my lord - had run away from them. Famine broke out among them and they ate the flesh of their children against their hunger ... On account of what have these calamities befallen Arabia? ... Because we did not keep the solemn oaths (sworn by) Ashur, because we offended the friendliness of Ashurbanipal, the king ..." (ix 15-16). 
As a Curse for Covenant Violation in the Old Testament

Leviticus 26:27-29:

"But if, despite this, you disobey me, and continue hostile to me, I will continue hostile against you in fury; I in turn will punish you sevenfold for your sins. You shall eat the flesh of your sons, and you shall eat the flesh of your daughters."

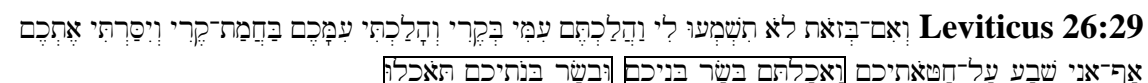

The Book of Leviticus starts with instructions for priestly sacrifice and the establishment of the priesthood (Lev 1-7 \& 8-10), then continues with purity rules and eventually the Holiness Code (Lev 11-15 \& 16 [17]-26) of which Leviticus 26 forms the conclusion with a collection of both blessings and curses. The five curses (vv. 14-45) are given more attention than the five blessings (vv. 1-13) and include war, famine and pestilence and it is within this context that the prediction is made that transgressors of the instructions will be reduced to eating the flesh of sons and daughters. ${ }^{5}$ Diagrammatically the relationship between blessings and the curses can be depicted as follows (Milgrom 2001:2286-2287):

First blessing: plenty (vv. 4-5)

Second blessing: peace (v. 6)

Third blessing: victory (vv. 7-8)

Fourth blessing: Abundant life (vv. 9-10)
First curse: $\quad$ illness, famine (vv. 14-17).

Second curse: drought \& poor harvest (vv. 18-20).

Third curse: harmful beasts (vv. 21-22).

Fourth curse: war, pestilence \& famine (vv. 23-26).

Fifth blessing: God's presence (vv. 11-12) Fifth curse: destruction \& exile (vv. 27-39).

Cannibalism is mentioned in verses 28-29 and forms part of curses associated with destruction and exile such as the abandonment of cult places (vv. 30-31), the desolation of the land (v. 32), as well as psychological disintegration [vv. 36-39] (Milgrom 2001:2290). Milgrom (2001:2315) seems to argue that cannibalism was a frequent theme in ancient Near Eastern curses and that it was "likely only when there was a shortage of food".

\section{Deuteronomy 28:53-57:}

"In the desperate straits to which the enemy siege reduces you, you will eat the fruit of your womb, the flesh of your own sons and daughters whom the Lord your God has given you. Even the most refined and gentle of men among you will begrudge food to his own brother, to the wife whom he embraces, and to the last remaining children, giving to none of them any of the flesh of his children whom he is eating, because nothing else remains to him, in the desperate straits to which the enemy siege will reduce you in all your towns. She who is the most refined and gentle among you, so gentle and refined that she does not venture to set the sole of her foot on the ground, will begrudge food to the husband she embraces, to her own son, and to her own daughter, begrudging even the afterbirth that comes out from between her thighs, and the children that she bears, because she is eating them in secret for lack of anything else, in the desperate straits to which the enemy siege will reduce you in your towns."

5 Carr (2010:152) points out that there is a difference of opinion about the demarcation of the Holiness Code and some scholars would define it as being Lev 17-26. 


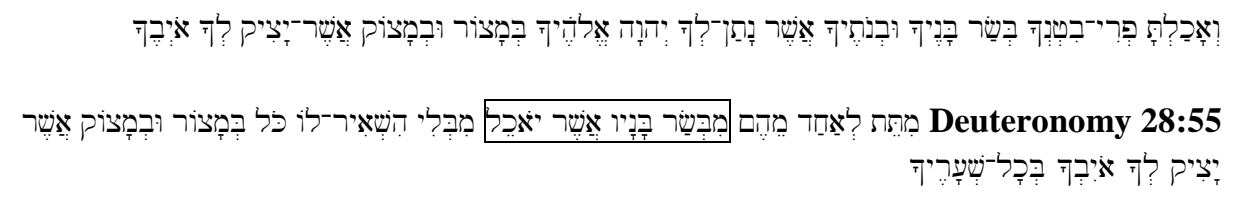

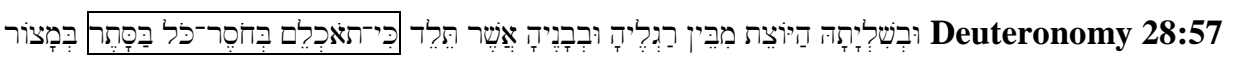

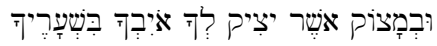

Striking similarities have been identified between Deuteronomy and Ancient Near Eastern treaties, both in terms of structure and content. The main body of legal instruction (Deut 12-26) is introduced by numerous speeches that recall aspects of the history of Israel. The so-called Deuteronomic Code is followed by blessings and curses that are dependent on the adherence to or breaking of the preceding laws and the ghastly references to different forms of cannibalism form part of the curses linked to disobedience to the legal obligations (Collins 2004:160-161; Carr 2010:140).

Deuteronomy 28 is the most extensive collection in the Old Testament of blessings and curses that starts off with blessings (vv. 1-14), followed by an elaborate sequence of curses that can be divided into three sections - all introduced by similar phrases: (vv. 15-44, 45-57 and 58-68). The 'enemy siege' leads to famine and this causes such desperation that different forms of compassion, such as the relationship between a husband and wife or between parents and children, are obliterated. ${ }^{6}$ There is a sharp contrast between the blessing in verse 4 ("Blessed shall be the fruit/issue of your womb") and the corresponding curse in verse 53 ("you will eat the fruit/issue of your womb"). The Hebrew be-matsor $u$-ve-matsok is translated with 'desperate straits' and is repeated in verses 55 and 57 to form a Leitmotif with rhyming words (Tigay 1996:270).

\section{Baruch 2:2-3:}

In the Apocrypha, a clear connection is made between the breaching of the covenant between God and his people and cannibalism as the inevitable consequence thereof (Hillers 1983:159):

"Under the whole heaven there has not been done the like of what he has done in Jerusalem, in accordance with the threats that were written in the Law of Moses. Some of us ate the flesh of their sons and others the flesh of their daughters."

The reference to the cannibalistic eating of children is a 'stock horror story of sieges' and is linked to the covenantal curses in Leviticus 26 and Deuteronomy 28. It forms part of a confession and prayer by the exilic Jewish community in Babylon that is to be read during festivals and that acknowledges Israel's sin and vindicates God (Saldarini 2001:951-952).

$6 \quad$ Tigay (1996:270, 489-494) describes how under such circumstances cannibalism has taken place throughout history, not only in Samaria and Jerusalem, but also elsewhere in the ancient Near East. 


\section{Kings 6:24-7:20: Siege of Samaria leads to a Famine that Causes Maternal Cannibalism}

2 Kings 6:28 But then the king asked her, "What is your complaint?" She answered, "This woman said to me, 'Give up your son; we will eat him today, and we will eat my son tomorrow."

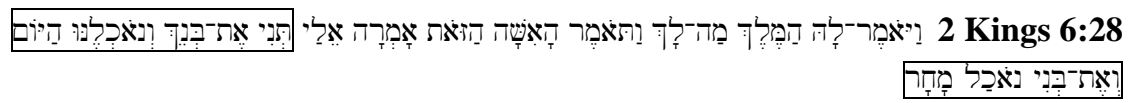

2 Kings 6:29: "So we cooked my son and ate him. The next day I said to her, 'Give up your son and we will eat him.' But she has hidden her son."

2 Kings 6:29 20

According to Fritz (2003:268) the description of the miraculous deliverance of Samaria in 2 Kings 6:24-7:20 can be divided in the following subsections: after an initial setting of the scene (6:24-25); three events are mentioned when subsequently the famine in Samaria is described 6:26, 28-30), followed by the discovery of the deserted Aramean camp (7:3-5, $8 b-11)$ and the eventual relief of the siege (7:12-16a).

In 2 Kings 6:20 a woman appeals to the king (Jehoram son of Ahab) of Israel for help (Sweeney 2007:310). ${ }^{7}$ The king responds by attributing the present disaster (famine and cannibalism) to YHWH and asks why he should wait for YHWH any longer (Lasine 1991:27-28).

Cannibalism is part of a vivid description of a society under siege coming apart at its moral seams - a world turned upside down where mothers bargain about sharing their children as food. ${ }^{8}$ Mothers who become agitated when other mothers do not share their children and not a word is mentioned about the horror of cannibalism! Lasine (1991:33) detects elements of tragic comedy in the mother who acknowledges eating children in public and in the presence of the king without any shame or sense of wrongdoing (similar dark humour is found in Judges 19:28 when the Levite commands his murdered concubine to get up!).

Is 2 Kings 6:24- 7:20 yet another episode in the so-called Deuteronomistic History "in which Israel gets the justice it deserved as the result of covenant disobedience?" (Lanner 1999:115). There is the disturbing alternative interpretive option not to view the maternal cannibalism as a ghastly example of the inhumanity caused by siege warfare, but to question who can be held responsible for these terrible events? ? $^{9}$ The king articulated both the fatalistic conviction that the Lord cannot help (6:27), as well the monotheistic presupposition that the evil comes from the Lord and that one will wait upon the Lord in vain (6:33).

Lanner (1999:114) reads this pericope from the perspective of the cannibalistic mother: "The most difficult aspect of the women's experience is knowing that food was only a miracle

The conduct of the unnamed king (possibly Jehoram son of Ahab son of Omri) is "characteristic of the dim view this literature has of the Omride kings" (Brueggemann 2000:355)

8 Fritz (2003:269) points out the underlying bitter irony of the maternal cannibalism: "in order to survive, people destroy their own future."

9 One should take into account that siege warfare was a military tactic used throughout the Ancient Near East 'to subdue a city' - a euphemistic reference to the horrors that emanated from a siege (Ferris 2009:390). 
away." If the very same narrative describes the miraculous lifting of the siege, one must ponder the reason why no miracle was available to rescue mothers from eating their children.

\section{Isa 9:19-20 \& Mic 3:3: The rulers of Israel eat the Flesh of God's People, who allows it!?}

Isaiah 9: 19-20:

Through the wrath of the LORD of hosts the land was burned, and the people became like fuel for the fire; no one spared another. They gorged on the right, but still were hungry, and they devoured on the left, but were not satisfied; they devoured the flesh of their own kindred;

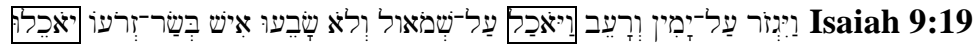

This reference to cannibalism forms part of the conclusion of a poem about the angry God in chapter 9:7-20 and in the third stanza (verses 17-20) the divine anger is expressed by the image of brush fire. An abrupt move is made from the burning landscape to a society in dire straits and according to Blenkinsopp (2000:215) cannibalism is used as a metaphor to depict 'a society in extremis'.

\section{Micah 3:3:}

"... who eat the flesh of my people, flay their skin off them, break their bones in pieces, and chop them up like meat in a kettle, like flesh in a caldron."

$$
\text { Micah 3:3 }
$$

Micah 3:1-4 form a bridging passage between Micah 2 where the rich is addressed and Micah 3 in which the ruling class is chastised (Kessler 2000:146-151). The prophet accuses the leaders of Israel of cannibalism - similar to Ez 34:2-3 where the shepherds of Israel are accused of feeding themselves on the sheep and not caring for them (a world turned upside down)! It would seem as if the leaders were expected to maintain justice and righteousness, but according to Micah 3:3 they not only neglected their duty, but brutally worked against it. $^{10}$

When one reads Micah 3:3 in close connection with Isaiah 9:19-20, one must seriously consider the possibility that the "true cannibals ... are the rulers of Israel who eat the flesh of God's people, and God, the Cannibal Parent, who allows it” (Lanner 1999:114).

\section{Jer 19:9: A curse for Torah Disobedience}

"And I will make them eat the flesh of their sons and the flesh of their daughters, and all shall eat the flesh of their neighbours in the siege, and in the distress with which their enemies and those who seek their life afflict them."

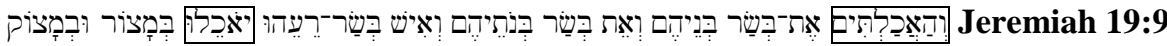

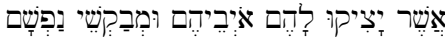

10 Kessler (2000:151) "die Machthaber in Jerusalem, die eigentlich für die Aufrechterhaltung des mishpat, der gerechten Ordnung, zuständig wären, nicht nur dieser Aufgaben nicht nachkommen, sondern sich selbst höchst aktiv und brutal daran beteiligen, 'das Fleisch meines Volkes ze fressen'”. 
As part of a description of a broken decanter in Jeremiah 19:1-13, verses 3 to 9 consist of two oracles, each with its own messenger formula and a petuchah at the end of verse 5 indicating the break between the oracles. The second oracle is introduced by hinneh and the messenger formula and the curse in verse 9 is similar to the curses found in the vassaltreaties of Esarhaddon.

Again siege conditions lead to 'unspeakable indignities' such as cannibalism (Lundbom 1999:836-840). It is important to note the first oracle (vv. 1-5) entails a judgment on the city (Jerusalem?) for covenant violations with the second oracle (vv. 6-9) continuing this judgment of the city and its inhabitants. Lundbom (1999:841-842) suggests that cannibalism is described in a way similar to 'child sacrifice' - as a desperate attempt to stop the siege and not to alleviate the hunger.

\section{Cannibalism in Lamentations 2:20}

According to Parry (2010:71) one can distinguish three sections in chapter 2: the destruction of Zion by God (vv. 1-10); the reaction to the calamity of Zion (vv. 11-19) and Zion's protest against God in the form of a prayer (vv. 20-22). ${ }^{12}$

Lamentations 2:20 Look, O LORD, and consider! To whom have you done this?

Should women eat their offspring, the children they have borne? Should priest and prophet be killed in the sanctuary of the Lord?

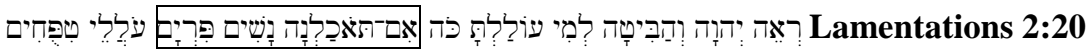

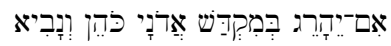

In the conclusion of the second section, verses $18-19$, it is not implied that Zion or Jerusalem had suffered unjustly, but in a rhetorically skilful way the poetic author attempts to move YHWH by describing the starving of children as the most vulnerable members of society for which a king (and a god?) have to take care of. Is the description of the misery of the people an attempt to 'arouse God's sympathy' or is it in fact an accusation of God because He either caused the suffering or at least allowed it. ${ }^{13}$

Verses 20-22 constitute the prayer of Zion (and the poet!). As part of the commemoration of the $9^{\text {th }}$ day of $\mathrm{Ab}$ these verses become the prayer of the suffering community. The accusation against God in the form of a prayer is neither blasphemy nor unique in the Old Testament (Bergant 2003:79). There are several examples in the Psalter where similar accusations form part of prayers of lament (Pss 22:1; 42:9 \& 88:14).

Verse 20 is introduced by the same imperative ('Look, O Lord') that Zion used in 1:11 (Provan 1991:77). The subsequent rhetorical questions in verse 20 whether women should eat their offspring and whether priests and prophets should be killed in the sanctuary or temple of YHWH function as motivation for the plea for divine attention and seem to imply that YHWH went too far in his wrath. ${ }^{14}$ Lady Zion or Jerusalem picks out both the children and the cultic personnel (priests and prophets) as objects of the Lord's harsh response and

11 Huey (1993:445): "There are twenty-two verses in chapters 1-2, corresponding with the twenty-two letters of the Hebrew alphabet. Each verse is composed of three lines; the first word of each verse begins with a consecutive Hebrew letter."

12 The poem in chapter 2 begins and ends with an inclusio like reference to the divine wrath manifested in the Day of the Lord (Parry 2010:72).

13 Berlin (2002:75) opted for the first reason.

14 Berlin (2002:75) considers the "picture of women devouring their children" to be "a particularly gruesome form of cannibalism signifying extreme famine." She goes on to say that cannibalism constitutes "a reversal of the natural order in which women feed their children." 
these two examples both function as rhetorically effective questions that elicit the same response: 'surely not!' (Parry 2010:85).

One could well ask what these two examples have in common. Berges (2002:165) suggests that some analogy might be presupposed between the intimacy that exists between a mother and child and the close relationship between YHWH and his priests and prophets. There might be different reasons for mentioning mother and child in close connection with the prophets and priests of YHWH: the women and children as examples of the vulnerable part of society, while the priests and the prophets were special intermediaries for God in society (Provan 1991:77). ${ }^{15}$

By means of two merisms the totality of the slaughter is depicted: no age group or gender will escape from this horrific punishment - every member of the inhabitants of Jerusalem (Zion) will suffer (Van Selms 1974:126).

It is striking that the manifestation of the Lord's angry judgement in verses 21 and 22 does not precipitate a plea for forgiveness from Zion but an accusation of God being complicit in the suffering of his people (Rudolph 1962:226). "Day of the Lord" terminology is used in verse 22 to accuse God and not the people! YHWH is in the final analysis held responsible for the suffering experienced during the destruction of Jerusalem. ${ }^{16}$

It is not clear, beyond any doubt, what the reference to maternal cannibalism in 2:20 means: ${ }^{17}$ it can either be an indication that mothers killed their children to eat them or that they were compelled by famine to eat their dead offspring to survive - both alternatives are grotesquely offensive (Parry 2010:84). ${ }^{18}$

\section{Cannibalism in Lamentations 4:10 ${ }^{19}$}

Although chapter 3 suggested a more hopeful future for Zion, Lamentations 4 refocuses the attention to the ongoing suffering of Zion and continues with similar topics as in chapter 2 with a "similar description of the suffering endured by various groups in the beleaguered city" (Bergant 2004:110).

Lamentations 4:10: The hands of compassionate women have boiled their own children; they became their food in the destruction of my people.

$$
\text { Lamentations 4:10 }
$$

15 Renkema (1998:323) argues that the murder of the priests in the sanctuary constitutes an ironic turn of events: "The very ones who normally took care of the slaughtering of animals for sacrifice are now themselves slaughtered in the very same place".

16 "One could well ask whether a God who slaughters his people is no less a cannibal than the mothers who eat their children" (Berlin 2002:76).

17 Renkema (1998:320) is convinced that one should not speak of cannibalism in this instance: "Human cannibalism is never related to exceptional situations of hunger, nor are the children of those involved its object".

18 In the Targum and the Midrash the maternal cannibalism is interpreted as the divine punishment of the people who killed the Lord's priests and prophets - the fate of Zechariah in 2 Chron 24:20-22 (Rudolph 1962: 227).

19 Lamentations 4 has twenty-two verses of two lines each (not the three lines found in the first three chapters of the book). The first word of each verse begins with the consecutive Hebrew letter, as is the custom with an acrostic poem (Huey 1993:445 note 11). 
Verse 10 forms the climax of a list of observations of the suffering of the inhabitants of Jerusalem in verses 1-10 (Salters 2010:308). One can detect an appalling sequence in the manner according to which the famine is described: first, the starvation of children is narrated (vv. 3-4); then the deterioration of the health of the adults (vv. 5-8); followed by the ironic observation that it is better to die quickly by the sword than slowly by famine (v. 9); culminating in "the ultimate trope for starvation: cannibalism (v. 10)" (Berlin 2003:103; Parry 2010:133). This horrific depiction of famine and destruction used maternal cannibalism to describe a world turned upside down - when compassionate women commit the unthinkable: ${ }^{20}$ when as mothers they boil their children with their own hands and not take care of them! $!^{21}$

It is interesting to note that the infinitive construct of barah I (to eat) is here translated as a noun. ${ }^{22}$ Only three other passages in the Old Testament employ this verb and all of them indicate eating when ill or in mourning ( 2 Sam $3: 35 ; 12: 17 ; 13: 5,7,10$ ). Renkema (1998:520) considers the description in 2 Samuel 13 to be of special importance: "It is a question of a type of food intended to build up the strength of a sick person or bring solace to someone who had endured great sorrow".

The ultimate horror of famine and siege - mothers cooking their children - leads the author to reflect on theological reasons for human suffering: The theological possibility suggested by Lamentations is that it was the anger or wrath of YHWH that destroyed Zion and Jerusalem (4:11).

No less than three words are used in verse 11 to emphasize the extent of the divine anger that caused the suffering endured by the inhabitants of Jerusalem (Bergant 2004:115116). Furthermore, there seems to be an analogy between the kind-hearted women eating their children in verse 10 and YHWH setting fire to Zion to devour her in verse 11 (Renkema 1998:518-519). ${ }^{23}$

There are numerous examples in the Old Testament where the extent of the transgression is reflected in its punishment ('eye for and eye,' etc.). Can the intensity of the wrath of God that gives rise to maternal cannibalism be explained by the extent of the initial breaking of the covenant or as an ironic criticism of the smugness of a pervasive "Zion theology that presupposed the inviolability of Jerusalem and the temple?" (Dearman 2002:466-467). This interpretation seems to resonate with the reaction to and the reasons provided for the terrible punishment: according to verse 12 the rest of the world could not believe that Jerusalem was conquered (a hyperbolic reference to the extent of Zion theology?) and in verse 13 the defiling sins of the prophets and priests of the temple in Jerusalem are indicated as the prime cause for the horrendous punishment (Rudolph 1962:252).

\section{Cannibalism in the Greco-Roman World}

20 O'Connor (2001:1062) points out that the reference to the cannibalistic mothers as being 'compassionate' entails a Hebrew wordplay on 'womb' (rahaminayôt and rehem).

21 Here the Pi of brh is used and not ' $k l$ and the LXX, P, V and T have translated it with 'food' and not with 'eating' - again an attempt to soften the horror of cannibalism. Berges (2002:249) refers to this incident as 'der Notkannibalismus (Teknophagie)' as an illustration of the ultimate struggle for survival.

22 The Piel infinitive construct barot with le has in the past been spuriously connected with an Akkadian loanword (labartu) that supposedly referred to a female demon of even a vampire. Most scholars, however, read it since as lamashtu (Van Selms 1974:141; Gottlieb 1978: 64-65).

23 The parallel use of the verbs 'akal and bashal indicate the close relatedness of verses 10 and 11 (Renkema 1998:518-519). 
Anthropophagy, as cannibalism was referred to in the Greco-Roman world, was considered to be one of the major threats to society. Accusations of anthropophagy were often used in Greek and Roman rhetoric in the negative symbolic stereotyping or labelling of enemies who threatened their society (McGowan 1994:412-443). As early as the Homeric epic, the Iliad provides an example of how anthropophagy was used as an idiom to describe how the human became a beast when warriors in the Trojan war were compared to blood thirsty predators - thus the rage of Achilles becomes cannibalistic when he expressed the urge to carve up his protagonist Hector's flesh and eat it (22:346-48).

In later Greco-Roman rhetoric the charge of cannibalism was often used as invective by authors such as Thucydides, Cicero, Seneca and Plutarch to vilify enemies like the Bacchanals, Cataline or Mark Anthony as 'cannibals'. ${ }^{24}$ This invective draws on GrecoRoman ethical theory "that articulates immorality not in terms of mere decline or degeneration but rather by the figure of inversion" - a form of mundus inversus! (Harrill 2008:138).

The Jewish historian, Flavius Josephus, also makes use of cannibalism in his description of the Jewish War against the Romans in which he depicts the opponents as bloodthirsty monsters "who eat the raw flesh and gulp down the warm blood of the very citizens they claim to protect". His description of the Roman siege of Jerusalem resonates with some of the cited Old Testament examples when he refers to the horrific incident when Mary bat Eleazar of Bethezuba, cooks up her baby for the conspirators as a type of sacrifice (Jewish War 6.201-19). Although Flavius Josephus is dated several centuries later than the most of the Old Testament references to different forms of cannibalism, it does illustrate the influence of Greco-Roman polemics on Jewish historiography.

Harrill (2008:133-158) in his study of cannibalism in the Fourth Gospel within the context of Greco-Roman polemics, poses a question that is also valid for the interpretation of the Old Testament and Lamentations in particular: "What specific connotations did the idiom of cannibalism have in the ancient Mediterranean world?"25

The short survey provided in the preceding paragraphs seems to provide numerous examples of how anthropophagy or cannibalism "functioned in ancient polemics to brand an opponent or faction in terms of the Other ..." (Harrill 2008:136). The Greco-Roman polemical rhetoric provides a context for at least considering references to cannibalism in Lamentations 2:20 and 4:10 as a motif in the criticism of YHWH as tyrant (the inverting Other!) that punishes beyond the parameters of retribution.

\section{Conclusion}

When reflecting on the function of cannibalism in Lamentations one has to bear in mind that its theological reflection is 'occasional, pluralistic, equivocating and fragmentary' and that there is no systematic development of any specific theme (Dobbs-Allsopp 2002:23).

One of the consequences of breaking the covenant between YHWH and Israel is severe famine and this can also cause parents eating the flesh of their children (Lev 26:29 and elaborated in Deut 28:53ff). Cannibalism is also related to the siege of Samaria ( $2 \mathrm{Kgs} 6: 28 \mathrm{ff})$ by the Assyrians $(722 \mathrm{BCE})$ and in prophetic literature as a sign of destruction (Jer 19:9; Ez 5:10 and Lam 4:10).

4 Pliny $(6,195)$ described the Ethiopians as 'cannibals'!

25 One should also bear in mind that Lamentations forms part of the Writings and that this third part of the Hebrew Bible was finally 'canonized' in the first century CE. This allows for ample opportunity to be influenced by Greco-Roman polemical rhetoric. 
The breaking of the covenant also leads to apostasy and internal disorder - a mundus inversus! Then the leaders/princes do not care for their subjects but devour them (Mic 3:3). One should be careful not to diminish the verb 'akal ('to eat, to devour') by resorting to metaphorical interpretations - although there might be some allusion to sacrifice, the existence of anthropophagy or cannibalism in times of siege and famine cannot be denied.

All five poems in Lamentations agree that the catastrophe with the destruction of Jerusalem is YHWH's punishment for $\sin (1: 6 ; 2: 14 ; 3: 42 ; 4: 13 ; 5: 16)$. YHWH is depicted as the Lord of history, who, despite the defeat and destruction of Jerusalem, is still able to punish foreign nations (i.e. Babylon in 2:1-9 and Edom in 4:21-22). Therefore, there is an obvious link between sin and punishment and the extent of the horrendous punishment is explained by the serious nature of the transgression. But further reflection is required because Greco-Roman rhetoric suggests additional reasons for the reference to eating of human flesh.

The rhetoric in Lamentations goes beyond a mere balancing act between deed and consequence or sin and punishment. Lamentations 2:20 and 4:10 are indignant accusations that YHWH has overstepped the parameters of cause and effect: it confronts YHWH with the suffering He has caused or allowed to happen and goes beyond the mere lamenting of the destruction of Jerusalem as the inevitable result of its perpetrated sins. "YHWH did what He planned to do" (2:17); "See, O YHWH, and take note!" (2:20). Mothers eating their children is an inversion due to divine planning and $\mathrm{YHWH}$ is held accountable for the suffering due to his wrath! $(4: 11){ }^{26}$

Greco-Roman rhetoric allows for the possibility that YHWH is depicted as a wrathful tyrant who has to take responsibility for the suffering caused by the destruction of Jerusalem! The Greco-Roman polemical rhetoric provides a context for at least considering references to cannibalism in Lamentations $2: 20$ and 4:10 as a motif in the criticism of YHWH as tyrant (the inverting Other!) that punishes beyond the parameters of retribution and who turns the moral order upside down - a mundus inversus in which mothers eat their own children.

In closing: Does Lamentations challenge its readers with the combination of the consequences of monotheism (no separate source for evil and suffering) and "la condition humaine" - lack of discernment about divine action?" (Van Selms 1974:128). ${ }^{27}$ These are possibilities that will require more scholarly attention in future.

\section{BIBLIOGRAPHY}

Andersen, ML and Taylor, HF 2002. Sociology. Understanding a Diverse Society ( $2^{\text {nd }}$ ed.). Belmont: Wadsworth/Thomson Learning.

Arens, W 1981. The Man-Eating Myth: Anthropology and Anthropophagy. New York: Oxford University Press.

Bergant, D 2004. Lamentations (AOTC). Nashville: Abingdon.

26 Renkema (1998:519) suggests a milder comparison between 2:20 and 4:10: "Where 2:20b placed the accent on the once well-cared-for and even spoiled children of Zion who are now confronted with this dreadful hunger, $4: 10 \mathrm{a}$ focuses on the emotions of their mothers and what they are forced by the same hunger to do to their dead children."

27 Dobbs-Allsopp (2002:103) argues that the defiance hid behind the veneer of rhetorical questions in Lamentations explode by means of the 'acrid accusation' of God as part of the resistance against suffering. Are we here faced with the combination of the consequences of monotheism (no separate source for evil and suffering) and 'la condition humaine'? (van Selms 1974:128). 
Berges, U 2002. Klagelieder (Herder). Freiburg: Herder.

Berlin, A 2002. Lamentations. A Commentary (OTL). Louisville: Westminster John Knox.

Blenkinsopp, J 2000. Isaiah 1-39 (Anchor Bible). New York: Doubleday.

Brueggemann, W 2000. 1 \& 2 Kings (SHBC). Macon: Smyth \& Helwys.

Carr, DM 2010. An Introduction to the Old Testament. Sacred Texts and Imperial Contexts of the Hebrew Bible. Chichester: Wiley-Blackwell.

Collins, JJ 2004. Introduction to the Hebrew Bible. Minneapolis: Fortress.

Cooper, JS 1983. The Curse of Agade. Baltimore: Johns Hopkins University Press.

Dearman, JA 2002. Jeremiah/Lamentations (NIV Application Commentary). Grand Rapids: Zondervan.

Dobbs-Allsopp, FW 2002. Lamentations (Interpretation). Louisville: John Knox.

Ferris, PW 2009. Lamentations, in JH Walton (ed.), Zondervan Illustrated Bible Backgrounds Commentary Volume 4. Grand Rapids: Zondervan.

Fritz, V 2003. 1 \& 2 Kings. A Continental Commentary (Augsburg). Minneapolis: Fortress.

Gottlieb, H 1978. A Study of the Text of Lamentations (Acta Jutlandica 48, Theology Series 12). Arhus: Odder.

Gray, J 1964. I and II Kings (OTL). London: SCM.

Harrill, JA 2008. Cannibalistic Language in the Fourth Gospel and Greco-Roman Polemics of Factionalism (John 6:52-66). JBL 127:133-158.

Hillers, DR 1983. History and Poetry in Lamentations. Currents in Theology and Mission 10:155-161.

Huey. FB 1993. Jeremiah and Lamentations (NAC). Nashville: Broadman.

Kessler, R 2000. Micha (Herder). Freiburg: Herder.

Kraus. H-J 1983. Klagelieder [Threni] (BKAT). Neukirchen: Neukirchener Verlag.

Lanner, L 1999. Cannibal mothers and me: A mother's reading of 2 Kings 6:24-7:20. JSOT 107-116.

LaBarbera, R 1984. The Man of War and the Man of God: Social Satire in 2 Kings 6:8-7:20. $C B Q$ 46:637-651.

Lasine, S 1991. Jehoram and the cannibal mothers (2 Kings 6:24-33): Solomon's judgment in an inverted world. JSOT 50:27-53.

Lundbom, JR 1999. Jeremiah 1-20 (Anchor Bible). New York: Doubleday.

McGowan, A 1994. Eating People: Accusations of cannibalism against Christians in the Second Century, JECS 2:413-442.

Milgrom, J 2001. Leviticus 23-27 (AB). New York: Doubleday.

Nelson, R 1987. First and Second Kings (Interpretation). Atlanta: John Knox.

O’Connor, K 2001. Lamentations, in L Keck (ed.), The New Interpreter's Bible Volume VI. Nashville: Abingdon.

Parry, R 2010. Lamentations. Grand Rapids: Eerdmans.

Provan, IW 1991. Lamentations (NCBC). Grand Rapids: Eerdmans. 
Reinhartz, A 1994. Anonymous Women and the Collapse of the Monarchy: A study in narrative technique, in A Brenner (ed.), A Feminist Companion to Samuel - Kings (The Feminist Companion to the Bible 5). Sheffield: Sheffield Academic Press, 43-65.

Renkema, J 1998. Lamentations (HCOT). Leuven: Peters.

Rudolph, W 1962. Das Buch Ruth - Das Hohe Lied - Die Klagelieder (KAT). Gütersloh: Gerd Mohn.

Saldarini, AJ 2001. The Book of Baruch, in L Keck (ed.), The New Interpreter's Bible Volume VI. Nashville: Abingdon.

Salters, RB 2010. A Critical and Exegetical commentary of Lamentations (ICC). London: T\&T Clark

Sweeney, MA 2007. I \& II Kings. A Commentary (OTL). Louisville: Westminster John Knox.

Tigay, JH 1996. Deuteronomy (JPS Torah Commentary). Philadelphia: JPS.

Van Selms, A 1974. Jeremia III \& Klaagliederen. Nijkerk: Callenbach. 